\title{
NORMAN MAILER
}

A CRITICAL STUDY

JEAN RADFORD

$\mathbf{M}$ 
- Jean Radford 1975

Softcover reprint of the hardcover 1st edition 1975 All rights reserved. No part of this publication may be reproduced or transmitted, in any form or by any means, without permission.

First published 1975 by THE MACMILLAN PRESS LTD London and Basingstoke Associated companies in New York Dublin Melbourne Fohannesburg and Madras SBN 333174097

ISBN 978-1-349-02404-9 ISBN 978-1-349-02402-5 (eBook) DOI 10.1007/978-1-349-02402-5 
for Luke 


\section{Contents}

Acknowledgements $\quad$ ix

Introduction 1

1 'The Beast and the Seer': Mailer's Search For a Hero

2 'A Revolution in the Consciousness of Our Time'

3 'The Best Writer in America' 76

4 'The Prisoner of Sex' 123

$\begin{array}{ll}\text { Conclusion } & 160\end{array}$

Epilogue on St. George and the Godfather and Marilyn 165

$\begin{array}{ll}\text { Notes } & 183\end{array}$

$\begin{array}{ll}\text { Selected Bibliography } & 195\end{array}$

$\begin{array}{ll}\text { Index } & 201\end{array}$ 


\section{Acknowledgements}

The author and publishers wish to thank the following for permission to use the extracts from Norman Mailer's works quoted in this study:

Jonathan Cape Ltd for Barbary Shore; Commentary for Richard Poirier's review, 'Morbid-Mindedness', of Norman Mailer's An American Dream, from Commentary (June 1965); Thomas Y. Crowell Co. Inc. for Miami and the Siege of Chicago, Copyright $\odot 1968$ by Norman Mailer; Andre Deutsch Ltd for Advertisements for Myself, The Presidential Papers, An American Dream, Cannibals and Christians, The Naked and the Dead, and The Deer Park; George Weidenfeld \& Nicolson Ltd. for The Prisoner of Sex, Miami and the Siege of Chicago, The Armies of the Night, and Why Are We in Vietnam?

Extracts from the following works are reprinted by permission of the author and the author's agents, Scott Meredith Literary Agency, Inc., 580 Fifth Avenue, New York, New York 10036: The Naked and the Dead, Barbary Shore, An American Dream, Cannibals and Christians, The Armies of the Night, Miami and the Siege of Chicago, The Prisoner of Sex, St. George and The Godfather, Marilyn, The Deer Park, Why Are We in Vietnam?, The Presidential Papers and Advertisements for Myself. 